\title{
EFEK DARI DYNAMIC COMPACTION (DC) TERHADAP PENINGKATAN KUAT GESER TANAH
}

\author{
Michelle Fauziek $^{1}$ dan Andryan Suhendra ${ }^{2}$ \\ ${ }^{1}$ Program Studi Sarjana Teknik Sipil, Universitas Tarumanagara, Jl. Letjen S. Parman No.1 Jakarta \\ maria_michelle@ymail.com \\ ${ }_{2}^{2}$ Program Studi Sarjana Teknik Sipil, Universitas Tarumanagara, Jl. Letjen S. Parman No.1 Jakarta \\ andryansuhendra@yahoo.com
}

\begin{abstract}
ABSTRAK
Perbaikan dan perkuatan tanah merupakan usaha yang dilakukan dengan tujuan untuk meningkatkan kualitas karakteristik tanah, utamanya parameter kuat geser tanah yang akan mendukung sebuah struktur sehingga mampu menahan beban struktur yang akan dibangun dengan deformasi yang dizinkan. Metode Dynamic Compaction merupakan metode perbaikan tanah dengan menjatuhkan beban (pounder) dari suatu ketinggian ke permukaan yang dipadatkan. Permukaan yang dipadatkan tersebut akan mengalami perubahan kepadatan relatif, yang kemudian akan dihitung menggunakan rumus empiris persentase kenaikan kepadatan relatif. Dengan menggunakan asumsi kenaikan kepadatan sebesar 15\%, maka perkiraan kenaikan qc setelah DC dapat dihitung dan didapatkan persentase kenaikan qc berkisar antara 16,98\% hingga $1731,23 \%$. Hasil yang diperoleh setelah menghitung persentase kenaikan kuat geser lapangan setelah DC yaitu grafik perbandingan berupa qc perkiraan dengan qc lapangan dan juga persentase kenaikan kepadatan yang terjadi setelah dilakukannya DC yang berkisar antara $0,28 \%$ hingga $101,83 \%$ dengan persentase kenaikan qc berkisar antara 1,08\% hingga 5961,54\%, serta pengaruh DC terhadap kedalaman dengan grafik dan sebagian besar kedalamannya melebihi hasil perhitungan.
\end{abstract}

Kata kunci: Dynamic Compaction, kepadatan relatif, CPT, kedalaman pengaruh.

\section{PENDAHULUAN}

\section{Latar Belakang}

Dalam ilmu teknik sipil, tanah memiliki peranan penting karena tanah digunakan sebagai pendukung kekuatan konstruksi dasar bangunan. Seiring berjalannya perkembangan infrastruktur yang pesat, lahan yang baik digunakan untuk infrastruktur semakin sedikit, sehingga semakin banyak infrastruktur yang dibangun di atas tanah yang kurang baik apabila dibangun struktur bangunan.

Sebelum membangun suatu bangunan di atas tanah harus melakukan tes terhadap tanah tersebut, terutama apabila tanah telah teridentifikasi sebagai tanah lunak. Tanah lunak pada umumnya mempunyai kekuatan geser lebih rendah dari tanah berbutir kasar. Apabila tanah lunak digunakan sebagai pendukung pondasi dan bangunan sangat tidak menguntungkan, karena akan banyak kerugian yang ditimbulkan. Meskipun kerusakan yang diakibatkan tidak bersifat mendadak dan langsung namun kerugian secara materi yang diakibatkan akan cukup besar. Maka dari itu, perlu diadakannya perbaikan tanah.

Perbaikan dan perkuatan tanah merupakan usaha yang dilakukan dengan tujuan untuk meningkatkan kualitas karakteristik tanah, utamanya parameter kuat geser tanah yang akan mendukung sebuah struktur sehingga mampu menahan beban struktur yang akan dibangun dengan deformasi yang diizinkan. Salah satu metode perbaikan tanah adalah metode Dynamic Compaction.

Metode Dynamic Compaction merupakan metode perbaikan tanah dengan menjatuhkan beban (pounder) dari suatu ketinggian ke permukaan yang dipadatkan. Metode ini biasanya digunakan untuk mencegah terjadinya likuifaksi, mencegah terjadinya penurunan, dan untuk memperbaiki daya dukung tanah.

\section{Tujuan Penelitian}

Berdasarkan latar belakang, tujuan dari penelitian ini adalah mendapatkan hasil perhitungan daya dukung tanah dan kedalaman pengaruh Dynamic Compaction berdasarkan data tanah yang tersedia; memperoleh hasil dari perkiraan persentase kenaikan kuat geser Dynamic Compaction dan persentase kenaikan lapangan; mengetahui perbandingan antara hasil perhitungan dengan hasil di lapangan setelah dilakukan perbaikan tanah. 


\section{Tanah}

Tanah adalah lapisan permukaan bumi yang berasal dari material induk yang telah mengalami proses lanjut, karena perubahan alami di bawah pengaruh air, udara, dan macam - macam organisme baik yang masih hidup maupun yang telah mati. Tingkat perubahan terlihat pada komposisi, struktur dan warna hasil pelapukan (Dokuchaev, 1870).

Kondisi geoteknik erat hubungannya dengan jenis tanah. Tanah dalam pengertian teknik secara umum dapat diartikan sebagai material yang terdiri dari agregat (butiran) mineral-mineral padat yang tidak tersementasi (terikat secara kimia) satu sama lainnya dan dari bahan-bahan organik yang telah melapuk (yang berpartikel padat) disertai dengan zat cair dan gas yang mengisi ruang-ruang kosong di antara partikel-partikel padat tersebut. Butiran-butiran mineral yang membentuk bagian padat dari tanah merupakan hasil dari pelapukan batuan. Ukuran setiap butiran padat tersebut sangat bervariasi dan sifat fisik dari tanah bergantung pada faktor ukuran, bentuk, dan komposisi kimia butiran. (Siahaan, 2015)

Tanah menurut Bowles (1991) adalah campuran partikel-partikel yang terdiri dari salah satu atau seluruh jenis berikut:

1. Berangkal (boulders), merupakan potongan batu yang besar, biasanya lebih besar dari $250 \mathrm{~mm}$ sampai $300 \mathrm{~mm}$. Untuk kisaran antara $150 \mathrm{~mm}$ sampai $250 \mathrm{~mm}$, fragmen batuan ini disebut kerakal (cobbles).

2. Kerikil (gravel), partikel batuan yang berukuran $5 \mathrm{~mm}$ sampai $150 \mathrm{~mm}$.

3. Pasir (sand), partikel batuan yang berukuran 0,074 mm sampai $5 \mathrm{~mm}$, berkisar dari kasar (3-5 mm) sampai halus (kurang dari $1 \mathrm{~mm}$ ).

4. Lanau (silt), partikel batuan berukuran dari 0,002 $\mathrm{mm}$ sampai 0,074 $\mathrm{mm}$. Lanau dan lempung dalam jumlah besar ditemukan dalam deposit yang disedimentasikan ke dalam danau atau di dekat garis pantai pada muara sungai.

5. Lempung (clay), partikel mineral berukuran lebih kecil dari 0,002 mm. Partikel-partikel ini merupakan sumber utama dari kohesi pada tanah yang kohesif.

6. Koloid (colloids), partikel mineral yang "diam” yang berukuran lebih kecil dari 0,001 mm.

Istilah tanah dalam bidang mekanika tanah dapat digunakan mencakup semua bahan seperti lempung, pasir, kerikil dan batu-batu besar. Metode yang dipakai dalam teknik sipil untuk membedakan dan menyatakan berbagai tanah, sebenarnya sangat berbeda dibandingkan dengan metode yang dipakai dalam bidang geologi atau ilmu tanah. Sistem klasifikasi yang digunakan dalam mekanika tanah dimaksudkan untuk memberikan keterangan mengenai sifat-sifat teknis dari bahan-bahan itu dengan cara yang sama, seperti halnya pernyataan-pernyataan secara geologis dimaksudkan untuk memberi keterangan mengenai asal geologis dari tanah.

\section{Pengertian Umum Stabilitas Tanah}

Dalam perekayasaan konstruksi bangunan sipil, sering ditemukan lapisan tanah yang memiliki daya dukung rendah (low strength), yang sangat mempengaruhi berbagai tahapan rancang bangun konstruksi, baik dalam tahap perencanaan (design), tahap pelaksanaan (perform), maupun tahap operasional dan pemeliharaan (Operational and Maintenance). Rendahnya daya dukung dari suatu jenis lapisan tanah di suatu tempat, sangat dipengaruhi oleh minerologi tanah, yang mana minerologi tanah terbentuk dari proses pelapukan material batuan (anorganik) dan/atau material organik. Hasil lapukan material anorganik dan organik yang membentuk lapisan tanah pada suatu tempat, dapat merupakan material lapukan setempat (residual soil), dan/atau hasil lapukan yang terangkut dari tempat lain (transported soil). Eksistensi kedua jenis material lapukan tersebut di dalam pembentukan lapisan tanah, sangat mempengaruhi sifat-sifat tanah pada suatu tempat. Baik sifat fisik maupun sifat teknis dari pada lapisan tanah. Jika partikel lapukan tersebut bergradasi halus, maka cenderung memberikan sifat yang kohesif dengan konsistensi fisis yang lunak. Sebaliknya jika partikel lapukan pembentuk lapisan tanah bergradasi kasar, maka cenderung memberikan konsistensi yang keras dan sifat yang cenderung non kohesif. Kedua karaktersitik tersebut (kohesivitas dan konsistensi), sangat menentukan kinerja dari lapisan tanah dalam berbagai hal, seperti besaran daya dukung, kapasitas permeabilitas tanah, perilaku kompresibilitas, dan potensi kembang susut (swelling potential) tanah. (Darwis, 2017)

Dalam pengertian teknis, terminologi dari pada daya dukung tanah adalah kemampuan tanah memikul tekanan dan/atau melawan penurunan akibat pembebanan, yaitu tahanan geser yang disebarkan oleh tanah di sepanjang bidang-bidang gesernya. Besaran daya dukung geser pada suatu lapisan tanah dipengaruhi oleh beberapa faktor, sebagaimana yang dirumuskan dengan persamaan Mohr-Coulomb sebagai berikut:

Keterangan:

$$
\tau=c+(\sigma-U) \cdot \tan \varphi
$$

$\tau=$ kuat geser tanah (daya dukung geser)

$\mathrm{c}=$ kohesi tanah

$\sigma=$ tegangan total tanah $=\gamma$ t.h $\gamma \mathrm{t}=$ berat volume tanah

$\mathrm{U}=$ tekanan pori tanah 
$\varphi=$ sudut geser dalam tanah

Dari formula di atas, terlihat jelas bahwa kohesivitas dan konsistensi tanah menjadi faktor yang menentukan besaran daya dukung geser tanah;

1. Nilai kohesi tanah, merupakan parameter kohesivitas yang sangat dipengaruhi adanya partikel tanah yang berbutir halus.

2. Sudut geser dalam tanah, berat volume tanah dan tekanan pori tanah, ketiganya merupakan parameter yang menunjukan konsistensi tanah, yang sangat dipengaruhi oleh adanya partikel bergradasi kasar.

Jika besaran daya dukung tanah dimaknai dalam arti kemampuan tanah dalam memikul tekanan aksial, maka beberapa parameter tanah yang berpengaruh, sebagaimana yang dirumuskan oleh Terzaghi dalam formula sebagai berikut:

Keterangan:

$$
\mathrm{q}_{\mathrm{u}}=\mathrm{c} \cdot \mathrm{Nc}+\mathrm{q} \cdot \mathrm{Nq}+1 / 2 \gamma \cdot \mathrm{B} \cdot \mathrm{N} \gamma
$$

$\mathrm{qu}=$ daya dukung aksial (ultimate)

$\mathrm{q}=$ tekanan overburden $=\gamma \cdot \mathrm{h}$

$\gamma=$ berat volume tanah

$\mathrm{B}=$ lebar konstruksi (pondasi) yang bertumpu pada tanah $=1 \mathrm{~m}$

$\mathrm{Nc}, \mathrm{Nq}, \mathrm{N} \gamma=$ Faktor daya dukung (FDD) dari Terzaghi.

Selanjutnya potensi kembang susut (swelling potential) dari tanah ekspansif dapat diperbaiki dengan cara merubah nilai density tanah tersebut (Holtz, 1959). Metode ini menunjukkan bahwa pemadatan pada nilai density yang rendah dan pada kadar air di bawah kadar optimum yang terlihat pada tes Standar Proctor dapat mengakibatkan lebih sedikit swelling potential daripada pemadatan pada nilai density, yang tinggi dan kadar air yang lebih rendah.

Menurut Darwis, pengertian lebih luas dari stabilisasi tanah adalah "suatu metode rekayasa tanah yang bertujuan untuk meningkatkan dan/atau mempertahankan sifat-sifat tertentu pada tanah, agar selalu memenuhi syarat teknis yang dibutuhkan". Dalam hal ini berbagai syarat teknis yang dibutuhkan dalam mengoptimalkan kinerja konstruksi, antara lain; kapasitas daya dukung tanah, kuat geser tanah, penurunan (settlement), permeabilitas tanah, dan lain sebagainya, yang mana syarat teknis tersebut selalu dikaitkan dengan jenis dan fungsi konstruksi yang dibangun/dibuat.

Secara garis besar, jika ditinjau dari mekanisme global yang terjadi pada tindakan stabilisasi tanah, maka klasifikasi tindakan stabilisasi tanah dapat dibedakan atas dua macam, yakni:

1. Perbaikan tanah (soil improvement), adalah suatu jenis stabilisasi tanah yang dimaksudkan untuk memperbaiki dan/atau mempertahankan kemampuan dan kinerja tanah sesuai syarat teknis yang dibutuhkan, dengan menggunakan bahan additive (kimiawi), pencampuran tanah (re-gradation), pengeringan tanah (dewatering) atau melalui penyaluran energi statis/dinamis ke dalam lapisan tanah (fisik).

2. Perkuatan tanah (soil reinforcement), adalah suatu jenis stabilisasi tanah yang dimaksudkan untuk memperbaiki dan/atau mempertahankan kemampuan dan kinerja tanah sesuai syarat teknis yang dibutuhkan, dengan memberikan material sisipan ke dalam lapisan tanah tersebut.

\section{Perbaikan Tanah}

Apabila mengacu pada klasifikasi dari stabilisasi tanah sebagaimana yang telah diuraikan sebelumnya, maka ruang lingkup dari perbaikan tanah meliputi dua klasifikasi, yakni:

1. Perbaikan tanah dengan metode kimiawi;

2. Perbaikan tanah dengan metode fisik;

Sebagaimana uraian pada bagian terdahulu bahwa perbaikan tanah terbagi atas dua kelompok, yakni perbaikan tanah secara kimiawi dan perbaikan tanah secara fisik. Kedua cara tersebut memiliki kesamaan dalam tujuan dan sasaran yang ingin dicapai, namun banyak perbedaan dalam metode maupun bahan pencampur (additive) yang dipergunakan.

\section{Dynamic Compaction}

Dynamic Compaction $(D C)$ adalah salah satu metode perbaikan tanah yang memiliki keunggulan waktu perbaikan tanah yang relatif lebih cepat dan murah dibandingkan dengan metode lain. Secara garis besar, pengertian DC adalah suatu metode peningkatan kondisi tanah yang dapat diterapkan pada tanah yang kering, basah/lembab dan jenuh (saturated). Metode ini bisa juga diterapkan pada tanah jenuh dengan kandungan butiran halus mencapai hingga $30 \%$. Target DC dicapai dengan menjatuhkan beban (pounder) dari suatu ketinggian tertentu ke atas permukaan tanah yang akan dipadatkan. Proses pemadatan ini berlangsung pada sekian banyak jatuhan pada lahan yang dituju. 


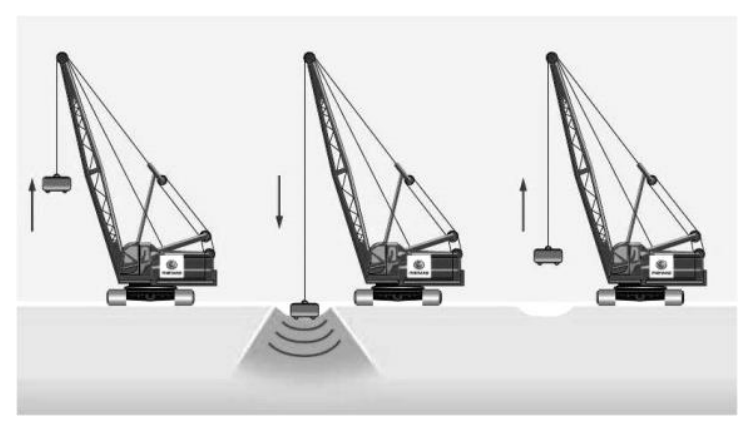

Gambar 1. Cara Kerja Metode DC

Sumber: Alamsyah, 2017

\section{Perencanaan Metode DC}

Berikut merupakan detail perencanaan yang harus disiapkan untuk metode DC:

A. Batasan area yang akan dipadatkan.

Pemadatan dengan metode ini memerlukan luasan tambahan sebesar nilai kedalaman rencana perbaikan (D) dari tepi luasan efektif pemadatan rencana.

B. Menentukan Berat dan Tinggi Jatuh Pounder.

Hubungan antara berat dan tinggi jatuh pounder untuk menentukan kedalaman rencana perbaikan dapat menggunakan rumus:

Keterangan:

$$
\mathrm{D}=\mathrm{n}(\mathrm{WH})^{0,5}
$$

$\mathrm{D}=$ Kedalaman rencana perbaikan $(\mathrm{m})$

$\mathrm{W}=$ Berat pounder (Ton)

$\mathrm{H}=$ Tinggi jatuh pounder $(\mathrm{m})$

$\mathrm{n}=$ Koefisien empiris

Pada rumus kedalaman rencana perbaikan di atas, $\mathrm{n}$ adalah faktor koefisien empiris yang bervariasi antara 0,3 dan 0,6. Nilai n 0,5 kemudian diusulkan oleh Leonards et al. (1980) atas dasar kompilasi data lapangan untuk sejumlah kondisi.

C. Menentukan besaran energi untuk menghasilkan perbaikan tanah yang diharapkan

Energi yang dihasilkan dari tumbukan pounder akan menyebabkan tanah memadat.

D. Kontrol Kedalaman Lubang Akibat Tumbukan Pounder.

1. Kontrol kedalaman lubang

Kedalaman lubang yang dihasilkan dari tumbukan pounder akan bervariasi. Hal ini mengakibatkan kedalaman perlu dikontrol dengan batas kedalaman tidak melebihi tinggi pounder ditambah 0,3 $\mathrm{m}$.

2. Kontrol heave.

Heave adalah naiknya permukaan tanah asli pada sisi lubang yang diakibatkan tumbukan pounder. Apabila heave terjadi, maka tumbukan harus segera dihentikan karena diasumsikan energi yang diterima tanah sudah mencapai optimum.

E. Stabilisasi Permukaan Tanah

Stabilisasi ini bertujuan agar alat berat yang beroperasi di area kerja dapat bermobilisasi dengan baik sehingga proses pelaksanaan menjadi efektif. Hal ini dilakukan jika kondisi tanah asli terlalu lepas.

\section{Tahapan Pemilihan Metode Dynamic Compaction}

A. Penyelidikan Tanah

Hal ini dimaksudkan untuk mengetahui data tanah awal dan mengelompokannya sesuai zona.

B. Perhitungan Daya Dukung Rencana

Setelah dilakukannya peyelidikan tanah, kemudian dilakukan perencanaan daya dukung yang akan diperoleh setelah melakukan DC. Perhitungan qc rencana tersebut dapat dilakukan dengan pengaruh terhadap kepadatan relatif tanah. Lee et al. (2004) menyimpulkan bahwa untuk mencari persentase kenaikan kepadatan relatif dapat menggunakan persamaan berikut:

$$
I_{r}=\frac{D_{r}-D_{r \min }}{D_{r \max }-D_{r} \min } \times 100(\%)
$$


Dimana $D_{r \text { min }}$ dan $D_{r \text { max }}$ adalah kepadatan relatif minimum dan maksimum setelah DC. Namun, karena kedua kuantitas tersebut belum dapat ditentukan dengan pasti sebelum dilaksanakannya DC, maka digunakan pendekatan dengan memperkirakan $\mathrm{D}_{\mathrm{r} \min }=\mathrm{D}_{\mathrm{r} 0}$ dan $\mathrm{D}_{\mathrm{r} \max }=100 \%$. Dengan pendekatan tersebut maka persamaan rumus menjadi:

$$
I_{r}=\frac{D_{r}-D_{r 0}}{100-D_{r 0}} \times 100(\%)
$$

C. Pemilihan Alat Berat.

Pemilihan alat berat didasarkan oleh energi tumbukan yang dapat dihasilkan dari alat berat. Besarnya energi tersebut ditentukan dari jenis alat berat, berat pounder dan tinggi jatuh.

D. Analisa Dampak Lingkungan

Analisa ini dimaksudkan untuk mengetahui seberapa besar efek yang diakibatkan oleh metode ini terhadap lingkungan sekitar.

E. Pelaksanaan Pemadatan

Pemadatan dilaksanakan sesuai dengan spesifikasi rencana baik pola, berat pounder, dan tinggi jatuh.

F. Kontrol Daya Dukung

Setelah proses pemadatan selesai, perlu dilakukan kontrol daya dukung kembali menggunakan pengujian lapangan.

\section{Parameter Tanah yang Digunakan}

1. Kategori Jenis Tanah

Untuk menentukan jenis tanah (Zone) sesuai dengan kategorinya akan menggunakan metode Robertson. Robertson telah memperbaharui Grafik sondir (Soil Behaviour Type) dengan menggunakan parameter sondir yaitu tahanan ujung $\left(\mathrm{q}_{\mathrm{c}}\right)$, dan juga friction ratio $(\mathrm{Rf})$.

\section{Faktor Daya Dukung}

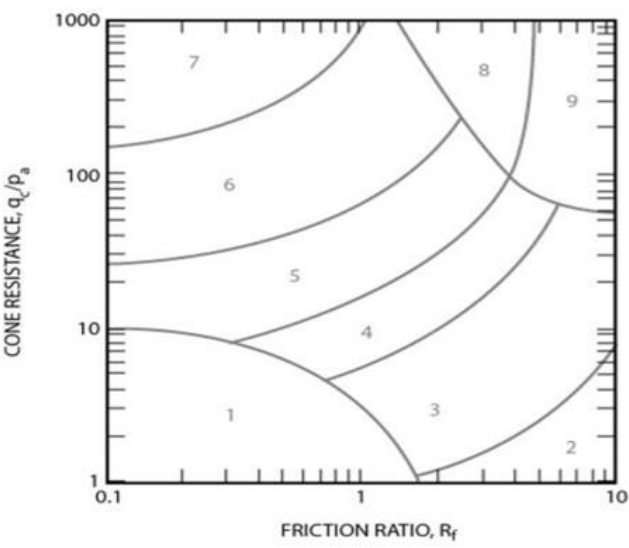

\begin{tabular}{|c|c|}
\hline Zone & Soil Behavior Type \\
\hline 1 & Sensitive, fine grained \\
2 & Organic soils - clay \\
3 & Clay - silty clay to clay \\
4 & Silt mixtures - clayey silt to silty clay \\
5 & Sand mixtures - silty sand to sandy silt \\
6 & Sands - clean sand to silty sand \\
7 & Gravelly sand to dense sand \\
8 & Very stiff sand to clayey sand \\
9 & Very stiff fine grained \\
\hline
\end{tabular}

* Heavily overconsolidated or cemented

$P_{a}=$ atmospheric pressure $=100 \mathrm{kPa}=1 \mathrm{tsf}$

Gambar 2. Grafik Soil Behaviour Type

Sumber: Djamhari, 2018

Untuk menghitung sudut geser dalam digunakan dua rumus empiris Meyerhof (1976) sebagai berikut:

$$
\begin{gathered}
\phi=29^{\circ}+2,5 \sqrt{q_{c}} \\
\phi=28^{\circ}+15 D_{r}
\end{gathered}
$$




\section{METODOLOGI PENELITIAN}

\section{Metode Pengumpulan Data}

Adapun pengumpulan data yang digunakan pada skripsi ini yaitu dengan mengumpulkan data-data penelitian yang berhubungan dengan topik yang dibahas kemudian dikumpulkan dan dilakukan perhitungan secara manual untuk mencari daya dukung dan kedalaman pengaruh tanah. Setelah mencari perkiraan kenaikan kuat geser dan perhitungan kedalaman pengaruh tanah kemudian dilakukan perbandingan dengan kuat geser dan kedalaman pengaruh yang dihasilkan setelah perbaikan tanah di lapangan.

\section{Metode Analisis Data}

Metode analisis yang digunakan untuk pengolahan data yaitu dengan Microsoft Excel. Sebelum dilakukannya analisis data, perlu adanya studi literatur dengan mencari dasar-dasar teori dan sumber data seperti jurnal, buku referensi untuk mendapatkan rumus-rumus untuk mendapatkan daya dukung tanah dan kedalaman pengaruhnya.

Metode perhitungan manual dalam analisis skripsi ini dilakukan untuk mencari kedalaman pengaruh dan perkiraan kuat geser. Setelah mencari perkiraan kuat geser tanah dengan metode perhitungan manual, akan dilakukan perbandingan antara kuat geser tanah dengan hasil data tanah di lapangan. Setelah mendapat hasil akhir perbandingan maka akan menjadi acuan dalam menentukan kesimpulan dari penelitian yang dilakukan.

\section{ANALISIS DAN PEMBAHASAN}

Pada bab ini, akan dilakukan pembahasan mengenai perhitungan daya dukung pada data hasil sondir sebelum dan setelah menggunakan Dynamic Compaction (DC) yang kemudian akan dibandingkan dengan hasil lapangan. Data tanah diperoleh dari salah satu proyek reklamasi yang terletak di Jakarta Utara, yang merupakan data hasil sondir (CPT) dan disajikan dalam bentuk tabel dan grafik.

\section{Rekap Hasil Analisis Data}

Perhitungan analisis dilakukan pada 5 data tanah yang diolah menggunakan Microsoft Excel dengan rekap hasil sebagai berikut:

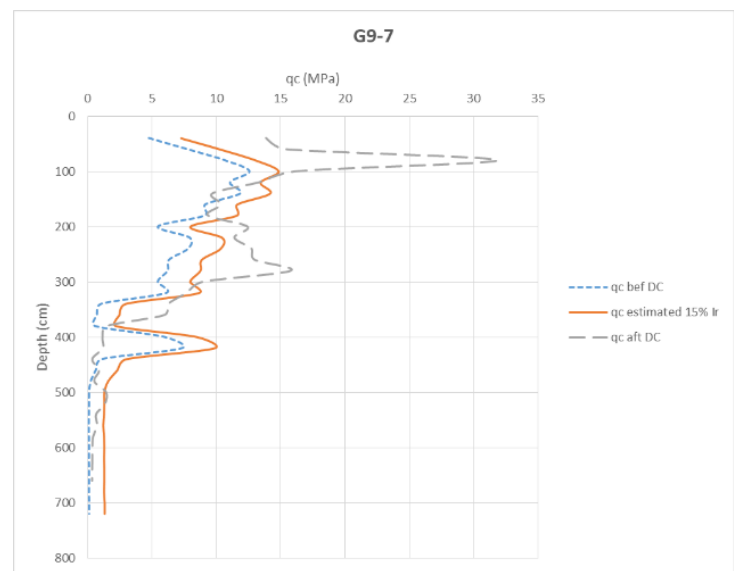

Gambar 4. Grafik Perbandingan q pada Titik G9-7

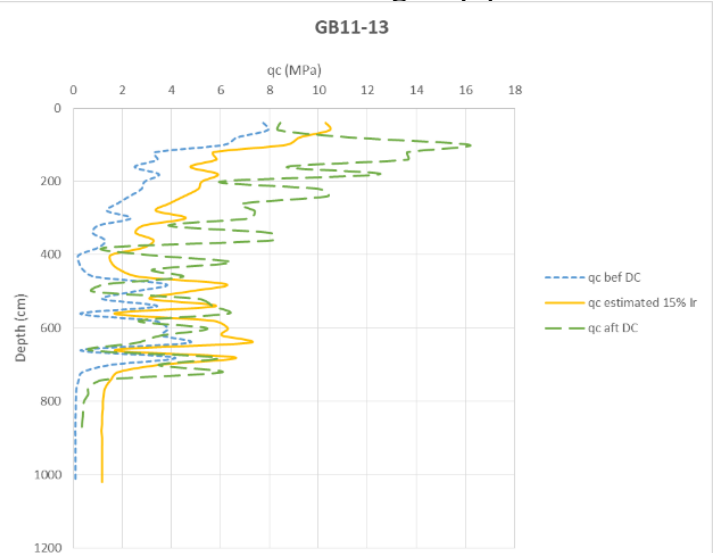

Gambar 5. Grafik Perbandingan $\mathrm{q}_{\mathrm{c}}$ pada Titik GB11-13 


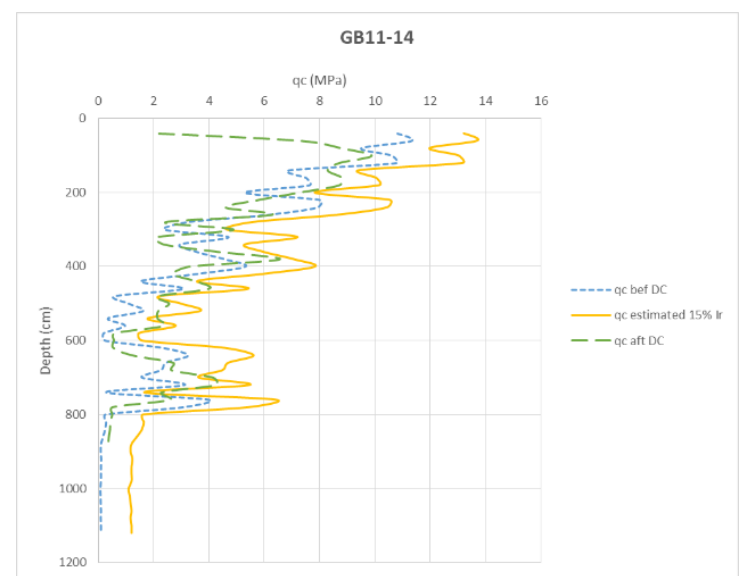

Gambar 6. Grafik Perbandingan $\mathrm{q}_{\mathrm{c}}$ pada Titik GB11-14

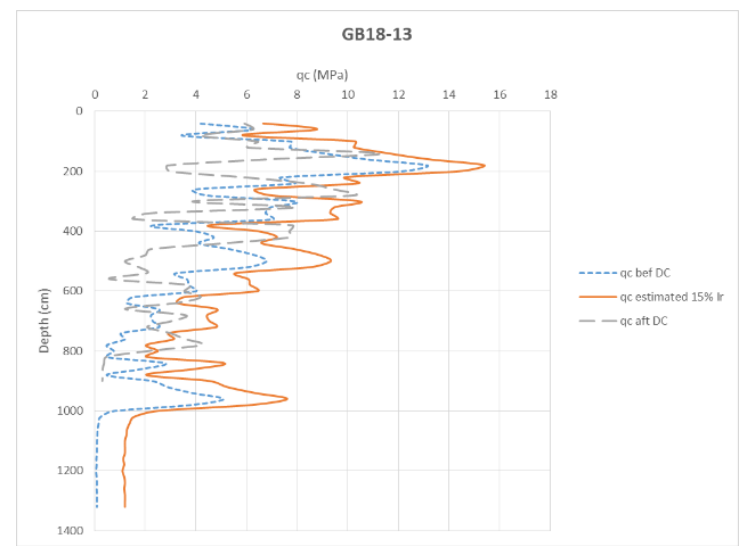

Gambar 7. Grafik Perbandingan q pada Titik GB18-13

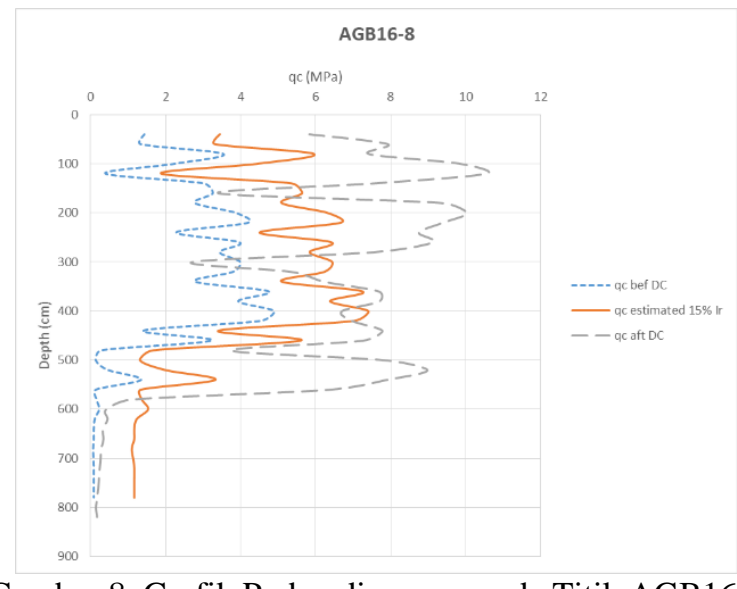

Gambar 8. Grafik Perbandingan $\mathrm{q}_{\mathrm{c}}$ pada Titik AGB16-8

\section{Analisis Perbandingan Kedalaman Pengaruh}

Pada proyek reklamasi yang terletak di Jakarta Utara ini, menggunakan 3 kali tahap penumbukan.

Tabel 1. Tahap Penumbukkan DC

\begin{tabular}{|c|c|c|c|}
\hline & Tahap I & Tahap II & Tahap III \\
\hline $\begin{array}{c}\text { Jumlah tumbukan } \\
\text { pounder }\end{array}$ & 5 & 5 & 5 \\
\hline $\begin{array}{c}\text { Berat pounder } \\
\text { (ton) }\end{array}$ & 15 & 15 & 10 \\
\hline $\begin{array}{c}\text { Tinggi jatuh } \\
\text { pounder }(\mathrm{m})\end{array}$ & 17 & 17 & 17 \\
\hline
\end{tabular}


Perbedaan hasil lapangan dengan perhitungan kedalaman rencana perbaikan dibuat menjadi sebuah kesatuan grafik.

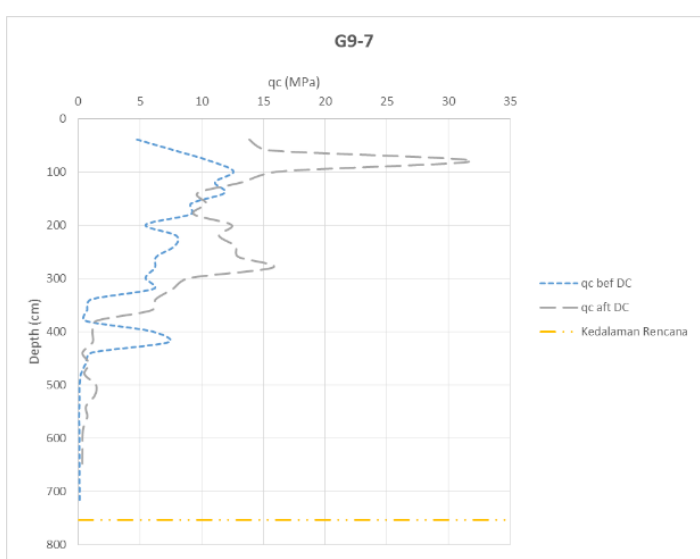

Gambar 9. Grafik Kedalaman pada Titik G9-7

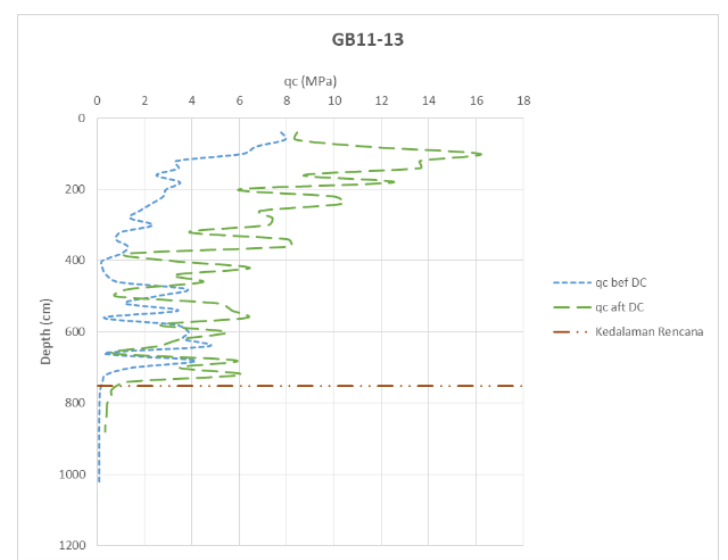

Gambar 10. Grafik Kedalaman pada Titik GB11-13

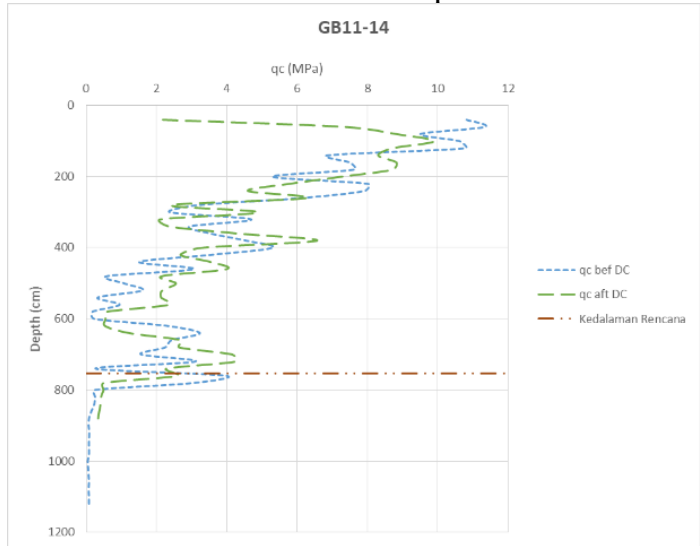

Gambar 11. Grafik Kedalaman pada Titik GB11-14 


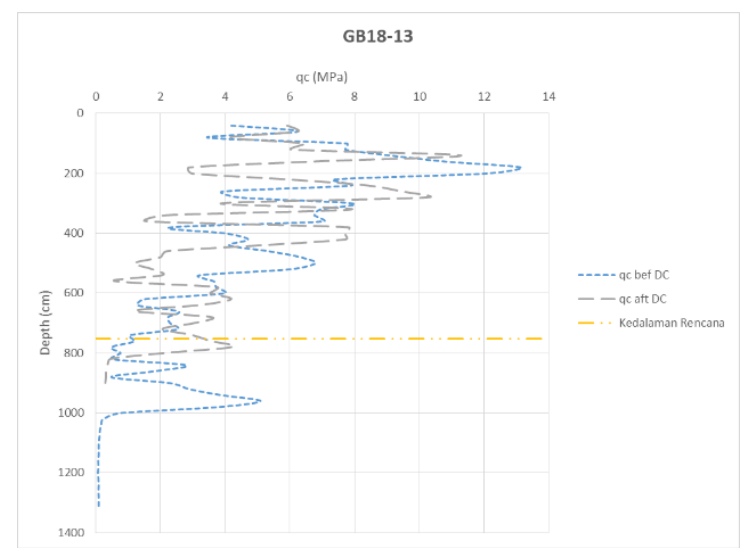

Gambar 12. Grafik Kedalaman pada Titik GB18-13

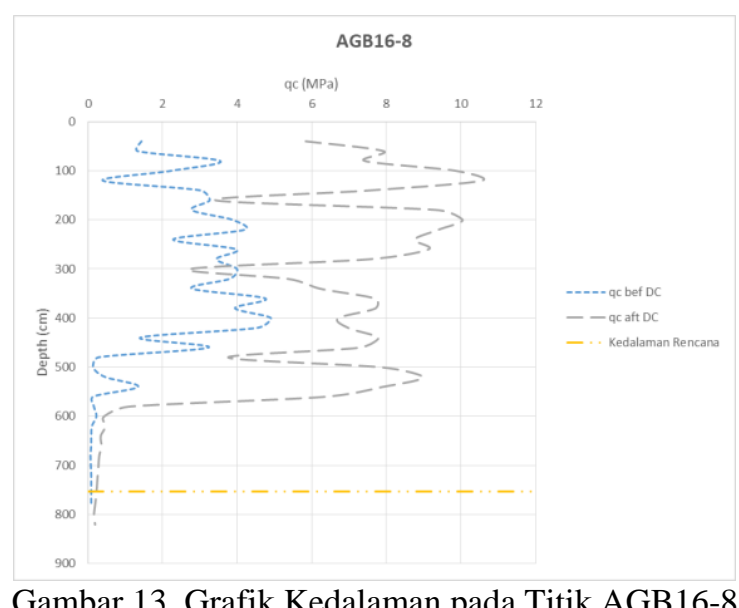

Pada grafik di atas didapatkan hasil perbandingan signifikan antara perhitungan rencana kedalaman dengan hasil kedalaman di lapangan, yang ternyata sebagian besar melebihi hasil perhitungan kedalaman rencana. Hal tersebut dapat dilihat pada tabel 3 berikut. 
Tabel 2. Hasil Analisis Rencana Kedalaman Pengaruh

\begin{tabular}{|c|c|c|c|}
\hline \multirow{3}{*}{$\begin{array}{l}\text { Data } \\
\text { Tanah }\end{array}$} & \multicolumn{3}{|c|}{ Kedalaman } \\
\hline & Sebelum & $\begin{array}{c}\text { Sesudah } \\
\text { DC }\end{array}$ & Teoritis \\
\hline & $\mathrm{cm}$ & $\mathrm{cm}$ & $\mathrm{cm}$ \\
\hline G9-7 & 720 & 660 & 753 \\
\hline GB11-13 & 1020 & 880 & 753 \\
\hline GB11-14 & 1120 & 880 & 753 \\
\hline GB18-13 & 1320 & 900 & 753 \\
\hline AGB16-8 & 780 & 820 & 753 \\
\hline
\end{tabular}

\section{KESIMPULAN}

Dari hasil analisis data qc dan kedalaman yang dilakukan dalam perhitungan dan grafik, dapat disimpulkan sebagai berikut:

1. Sebagian besar jenis tanah dari lima data tanah tergolong kategori pasir sehingga merupakan tanah yang cocok untuk menggunakan metode Dynamic Compaction.

2. Dari hasil perhitungan analisis berdasarkan lima data tanah, didapatkan persentase kenaikan kepadatan yang terjadi setelah dilakukannya DC berkisar antara 0,28\% hingga 101,83\%.

3. Pada analisis kenaikan kepadatan relatif lapangan ada pula yang mengalami penurunan kepadatan di beberapa titik kedalaman tanah.

4. Dengan asumsi kepadatan relatif sebesar 15\%, didapatkan persentase kenaikan qc berkisar antara 16,98\% hingga $1731,23 \%$. Sementara persentase kenaikan qc lapangan berkisar antara 1,08\% hingga 5961,54\%.

5. Dari hasil analisis terhadap kedalaman perbaikan pada lima data tanah yang tersedia, terdapat empat titik yang melebihi perkiraan kedalaman rencana dan satu titik lokasi yang kurang dari perkiraan kedalaman rencana perbaikan (titik G9-7).

6. Berdasarkan seluruh data CPT dari lapangan, didapatkan pengaruh kedalaman efektif rata-rata Dynamic Compaction sebesar 8,2 meter, sementara hasil perhitungan kedalaman rencana perbaikan sebesar 7,53 meter. Hal ini berarti pengaruh DC yang didapat di lapangan melebihi perkiraan dari perhitungan secara teoritis.

\section{DAFTAR PUSTAKA}

Alamsyah, Firman. 2014. Perbaikan Daya Dukung Tanah dengan Metoda Dynamic Compaction. Skripsi. Surabaya: Institut Teknologi Sepuluh Nopember.

Bowles, J.E. 1991. Sifat-sifat Fisis dan Geoteknis Tanah (Mekanika Tanah) Edisi kedua. Jakarta: Penerbit Erlangga. Darwis, H. 2017. Dasar - Dasar Teknik Perbaikan Tanah. Yogyakarta: Pustaka AQ.

Dokuchaev. 1870. Mekanika Tanah. Jakarta: Penerbit Erlangga.

Siahaan, A. P. 2015. Material Tanah dan Batuan. Makalah. 